\title{
Surgical Timing of the Subependymal Giant Cell Astrocytoma (SEGA) with the Patients of Tuberous Sclerosis Complex
}

\author{
Tüberus Sklerozis Kompleksli Subependimal Dev Hücreli Astrositomlu \\ Hastalarda Cerrabi Zamanlama
}

\author{
Mehmet Ali EKICI ${ }^{1}$, Sefer KUMANDAS ${ }^{2}$, Huseyin PER ${ }^{2}$, Arzu EKICI ${ }^{3}$, Bulent TUCER ${ }^{5}$, Hakan GUMUS², \\ Ozlem CANOZ ${ }^{4}$, Ali KURTSOY 5 \\ ${ }^{1}$ Bozok University, Faculty of Medicine, Department of Neurosurgery, Yozgat, Turkey \\ ${ }^{2}$ Erciyes University, Faculty of Medicine, Department of Pediatric Neurology, Kayseri, Turkey \\ ${ }^{3}$ Osmangazi University, Faculty of Medicine, Department of Pediatric Neurology, Eskisehir, Turkey \\ ${ }^{4}$ Erciyes University, Faculty of Medicine, Department of Pathology, Kayseri, Turkey \\ ${ }^{5}$ Erciyes University, Faculty of Medicine, Department of Neurosurgery, Kayseri, Turkey
}

Correspondence address: Mehmet Ali EKICI / E-mail: mehmetali.ekici@gmail.com

\begin{abstract}
AIM: Tuberous sclerosis complex has shown a wide variety of clinical, pathologic and radiologic manifestations. Many tumor types are found in tuberous sclerosis, which includes subependimal giant cell astrositoma. The aim of this study is to focus on surgical timing of the tumor.

MATERIAL and METHODS: This study included 37 children with tuberous sclerosis presenting to Erciyes Univercity Medical School, whose hospital record were retrospectively evaluated between 1995 and 2010. Of the 5 patients had diagnosed with the subependymal giant cell astrocytoma and three patients were opereted on.

RESULTS: In the 27 of the patients had subependimal nodules (73\%), cortical tubers were in the 19 patients (51,4\%), giant cell astrositoma (SEGA) were in the 5 patients (13,5\%). Mental retardation in different level was detected in the 18 patients $(48.6 \%)$. The other clinical findings of the patients were angiomyolipomas (37.8\%), hypomelanotic macules (91.9\%), Convulsion (54.1\%), adenoma sebaceum (32.4\%) , West syndrome (16.22\%), shagreeen patch (16.2\%), intracardiac tumor (37.8\%), subungual fibroma (2.7\%), fibroadenom in the neck (2.7\%).

CONCLUSION: A multidisciplinary approach is essential for an early, accurate diagnosis and proper management of affected individuals. The early surgical menagement for subependimal giant cell astrocytoma are recommended, and also periodic monitoring even for asymptomatic patients with subependymal nodules.
\end{abstract}

KEYWORDS: Tuberous sclerosis complex, Subependymal giant cell astrositoma, Surgical timing

öz

AMAÇ: Tüberus sklerozis kompleks klinik, patolojik ve radyolojikolarak geniş bir çeşitlilik göstermektedir. Subependimal dev hücreli astrositomanın dahil olduğu birçok tümör tipi bulunur. Bu çalışmanın amacı tümörün cerrahi zamanlamasına dikkat çekmek.

YÖNTEM ve GEREÇ: Erciyes Üniversitesi Tıp Fakültesi Hastanesi'nde 1995-2010 yılları arasında hasta kayıtları geriye dönük olarak değerlendirildi ve 37 tüberus sklerozisli hasta çalışmaya dahil edildi. Hastaların 5'ine subependimal dev hücreli astrositom tanısı konuldu ve üç hasta ameliyat edildi.

BULGULAR: 27 hastada (\%73) subependimal nodul, 19 hastada (\%51.4) kortikal tuber, 5 hastada (\%13.5) dev hücreli astrositom vardı. 18 hastada (\%48.6) farklı seviyelerde mental retardasyon tespit edildi. Hastaların diğer klinik bulguları; anjiyomyolipom (\%37.8), hipomelanotik makul (\%91.9), konvulzyon (\%54.1), adenoma sebaseum (\%32.4), west sendromu (\%16.2), shagreen lekeleri (\%16.2), intrakardiak tümör (\%37.8), subungual fibroma (\%2.7), boyunda fibro adenomdu (\%2.7).

SONUÇ: Etkilenmiş bireylerin erken, doğru ve uygun tedavisi için multidisipliner yaklaşım esastır. Subependimal dev hücreli astrositomada erken cerrahi önerilir ve de subependimal nodullü hastalar için peryodik izleme önerilir.

ANAHTAR SÖZCÜKLER: Tüberus sklerozis kompleks, Subependimal dev hücreli astrositom, Cerrahi zamanlama 


\section{INTRODUCTION}

Tuberous sclerosis complex (TSC) is a multisystem genetic disorder that occurs in approximately 1 in 5.800 to 10,000 individuals $(24,35)$. TSC may cause hamartomatous lesions of all organs but primarily affects tissues of the skin, central nervous system, kidneys, eyes, heart, and lungs. The disease is characterized by a broad physical phenotypic spectrum with epilepsy, mental retardation, renal dysfunction, and dermatologic abnormalities $(26,27,32)$. The pathogenesis of TSC lies in the expression and function of the gene products, tuberin in TSC2 and hamartin in TSC1, in tissue $(7,21,36)$.

The classic TSC central nervous system findings of cortical tubers, subependymal nodules (SENs), subependymal giantcell astrocytomas (SEGAs), and white-matter abnormalities are now easily identified by modern neuroimaging techniques $(3,4,17,19,20)$. SEGAs are benign tumors that occur in approximately $10 \%$ of patients with TSC. They are associated with TSC and believed to originate from subependymal TS nodules. SEGAs are clinically significant because enlargement of these lesions may obstruct the flow of cerebrospinal fluid through the foramen of monro, causing obstructive hydrocephalus $(5,6,13,31)$.

We report 37 patients with tuberous sclerosis complex, which include 5 patients with subependymal giant cell astrocytomas. Of these patients with SEGA, three have been treated with surgical resection.

\section{MATERIAL and METHODS}

This study included 37 children with tuberous sclerosis presenting to Erciyes University Medical School during the 15-year period from 1995 to 2010. The Patients' hospital records for this period were scanned retrospectively. The diagnosis of TSC was made according to the criteria given by Roach at al (Table I). The patients with the diagnosis of tuberous sclerosis were observed retrospectively. The study group was chosen from among the patients who had come to the pediatric neurology department with the complaints of epilepsy and mental motor retardation (MMR). MRI and CT demonstrated neurotubers, as well as allowing us to determine the involvement, if any,of other organs. For this purpose, renal, cardiac, ophthalmic and cutaneous scans were obtained. Controls and scannings were repeated every three months especially for the patients having the brain and renal involvement. In order to determine the patients' intelligence level, Denver II development test for patients under, and WISC-R test for those above , 6 years of age, were performed. The data obtained were saved at each control. Because of the obstructive hydrocephaly development risk due to foramen of monro compression, MRI and CT were performed each year for the patients with SEGA. Of the 5 patients with the diagnosis of subependymal giant cell astrocytoma, three were operated on with the anterior transcallosal approach.

\section{Patient Reports}

\section{Patient 1}

A 14-year-old boy presented with headache and hyperactivity and seizures. The patient had been diagnosed with tuberosclerosis earlier when he was only 5 months old. He had cortical tuber and subependymal giant cell astrocytoma (SEGA) in the brain and hypomelanotic macules on the skin (Table III). MR disclosed a mass in the left and right ventricular anterior horn at the level of the foramen of monro (Figure 1 A-D). The patient was operated on. The navigation was used intraoperatively for planning and during the surgery. Under general anesthesia and after Mayfield's spiky heading binding, the position of the patient was matched using neuronavigation. Anterior interhemispheric transcallosal approach was performed. The pericallosal artery was anomalous as azygos shape when the corpus callosum was reached. Subsequently callosotomy was performed, and passed over above the pericallosal artery and the right lateral ventricle was reached. The corpus and genu of the lateral ventricle were filled with the mass. The lesion was macroscopically consistent with astrocytomas, and firstly debulking was performed and then subtotal resection was done because the lesion had no favorable cleavage plane with adhesion to the head of the caudate nucleus. The lateral side of the mass was resected subtotally to control bleeding. Secondly, septum pellicidum was opened to reach the left lateral ventricle followed by the total resection of the mass that was moderately hemorrhagic and infiltrative into the neural tissue near the foramen monro. Although no acute hydrocephaly occurred in the early postoperative period, a burrhole was opened on the right side, $1 \mathrm{~cm}$ away from the anterior of the coronal suture, to save time. The postoperative course was uneventful. Histological examination disclosed a highly cellular neoplasm with marked pleomorphism. In this case, the clustering of tumor cells and perivascular pseudopalisading was striking (x 100, H-E). Prominent giant cells and numerous atypical mitotic figures were found (Figure 2). The picture was consistent with SEGA.

\section{Patient 2}

A 15-year-old girl presented with headache and seizures and vomiting. The patient had been diagnosed with tuberosclerosis when she was 15 months old. She had cortical tuber and subependymal giant cell astrocytoma (SEGA) in the brain and hypomelanotic macules on the skin and renal angiomyolipoma (Table III). MR disclosed a mass in the right ventricular anterior horn at the level of the foramen monro (Figure $3 \mathrm{~A}-\mathrm{D}$ ). The patient had pupil edema on fundoscopy. The patient was operated on owing to the symptoms of increased intracranial pressure. Navigation was used intraoperatively for plannning and during the surgery. Under general anesthesia, and after Mayfield's spiky heading binding, the position of the patient was matched using neuronavigation.. Anterior interhemispheric transcallosal approach was performed. The pericallosal artery was passed over to reach the corpus callosum. Subsequently, callosotomy was performed and the right lateral ventricle was reached. The anterior and posterior margin of the tumor was found and debulked with ultrasonic surgical aspirator (CUSA). The tumor was resected completely and the foramen monro was opened. The lesion was macroscopically consistent with astrocytomas, and was 


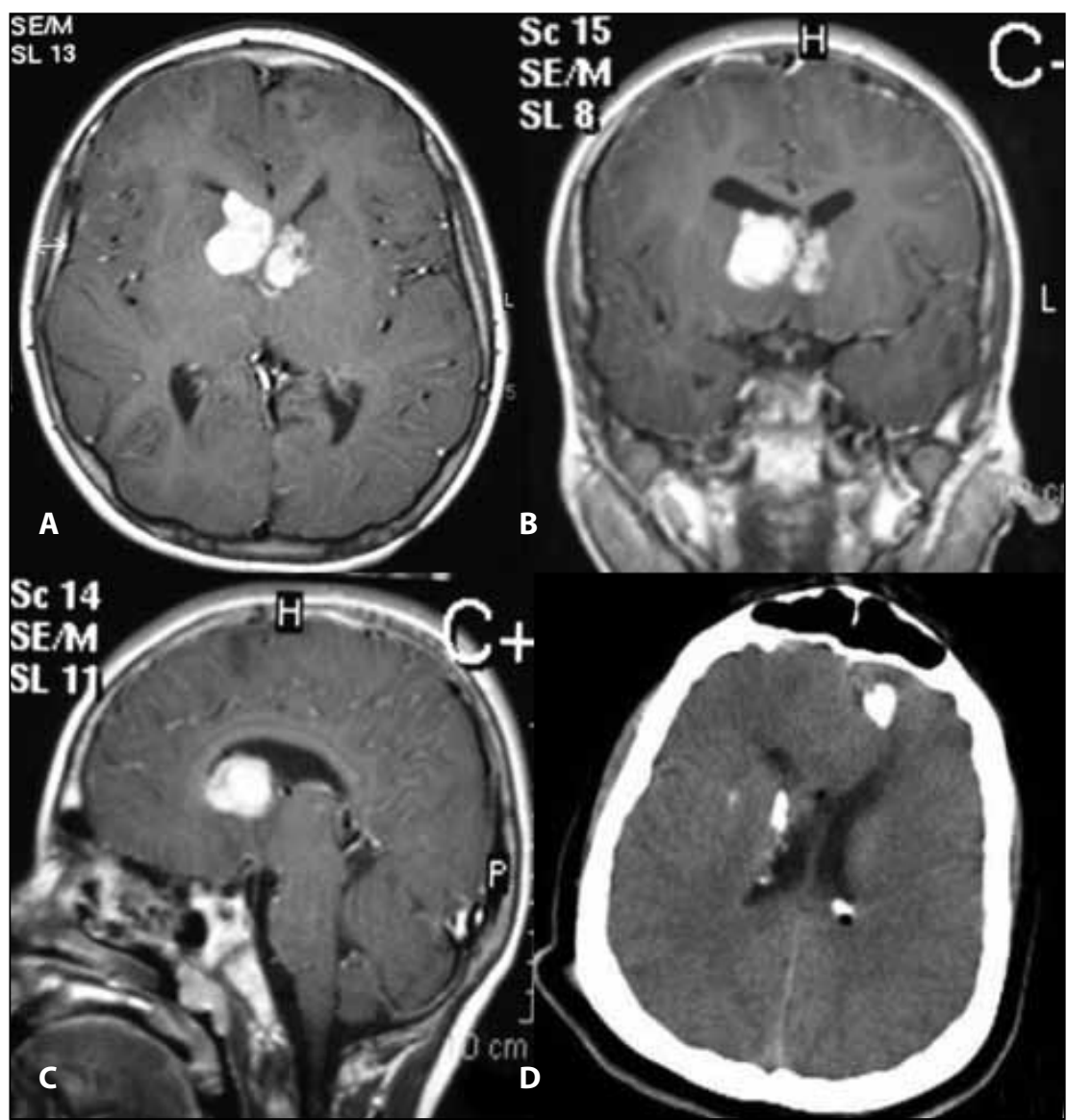

Figure 1: A) Preopeative MR axial section with contrast revealed that tumor located on right and left lateral ventricule anterior horn. B) Preopeative MR coronal section with contrast also demonstrated that tumor located on next to the foramen monro. C) Preopeative MR saggital section with contrast showed the tumor.

D) Postoperative CT section showed that the tumor located on the left vetricule was totally removed but, the tumor located on the right ventricule was subtotal removed.

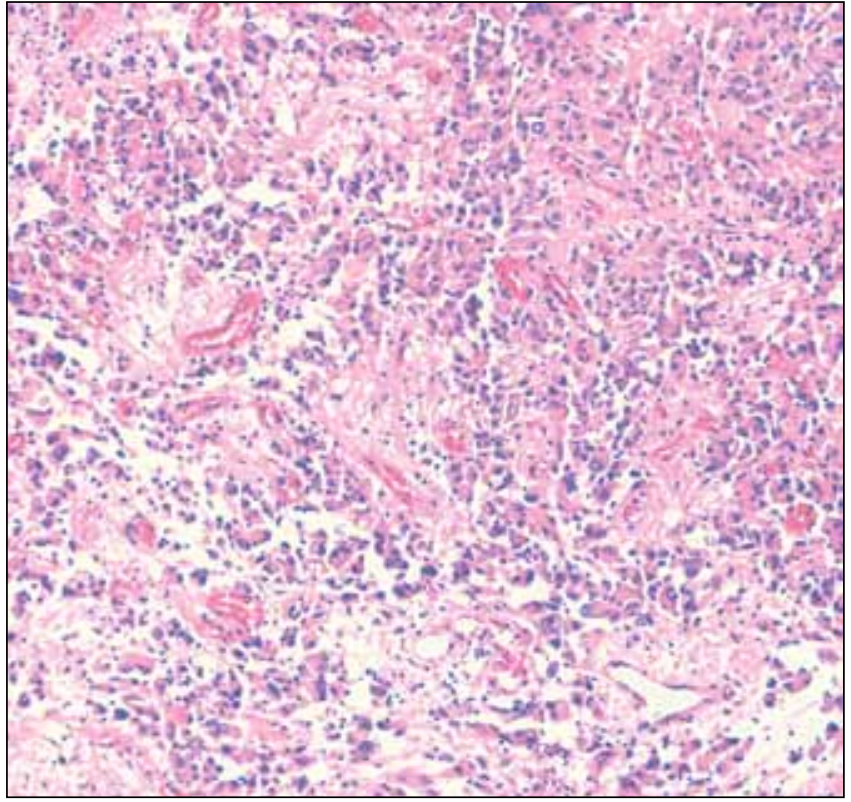

Figure 2: In this picture clustering of tumor cells and perivascular pseudopalisading were striking $(x 100, \mathrm{H}-\mathrm{E})$. moderately hemorrhagic and infiltrative to the neural tissue level the near of the foramen monro. The postoperative course was uneventful. Histological examination disclosed a highly cellular neoplasm with marked pleomorphism. Reticulin was abundant in the stroma. Tumor cells demonstrated GFAP positivity (x100, Immunoperoxidase) (Figure 4). The picture was consistent with SEGA.

\section{Patient 3}

An 11-year-old girl presented with headache and seizures and vomiting. The patient was diagnosed with tuberous sclerosis when she was admitted the hospital. She had cortical tuber and subependymal giant cell astrocytoma (SEGA) in the brain and hypomelanotic macules on the skin of the lumbar and left knee and renal angiomyolipoma (Table III). MR disclosed a mass in the right ventricle anterior horn and at the level of the foramen of monro (Figure 5A-D). The patient had pupil edema on fundoscopy. She was operated on owing to the symptoms of elevated intracranial pressure. The navigation was used intraoperatively for planning and during the surgery. Under general anesthesia, after Mayfield's spiky heading binding, the position of the patient was matched using neuronavigation. Anterior interhemispheric transcallosal approach was performed. The pericallosal artery were passed over and the corpus callosum was reached. Following callosotomy, 


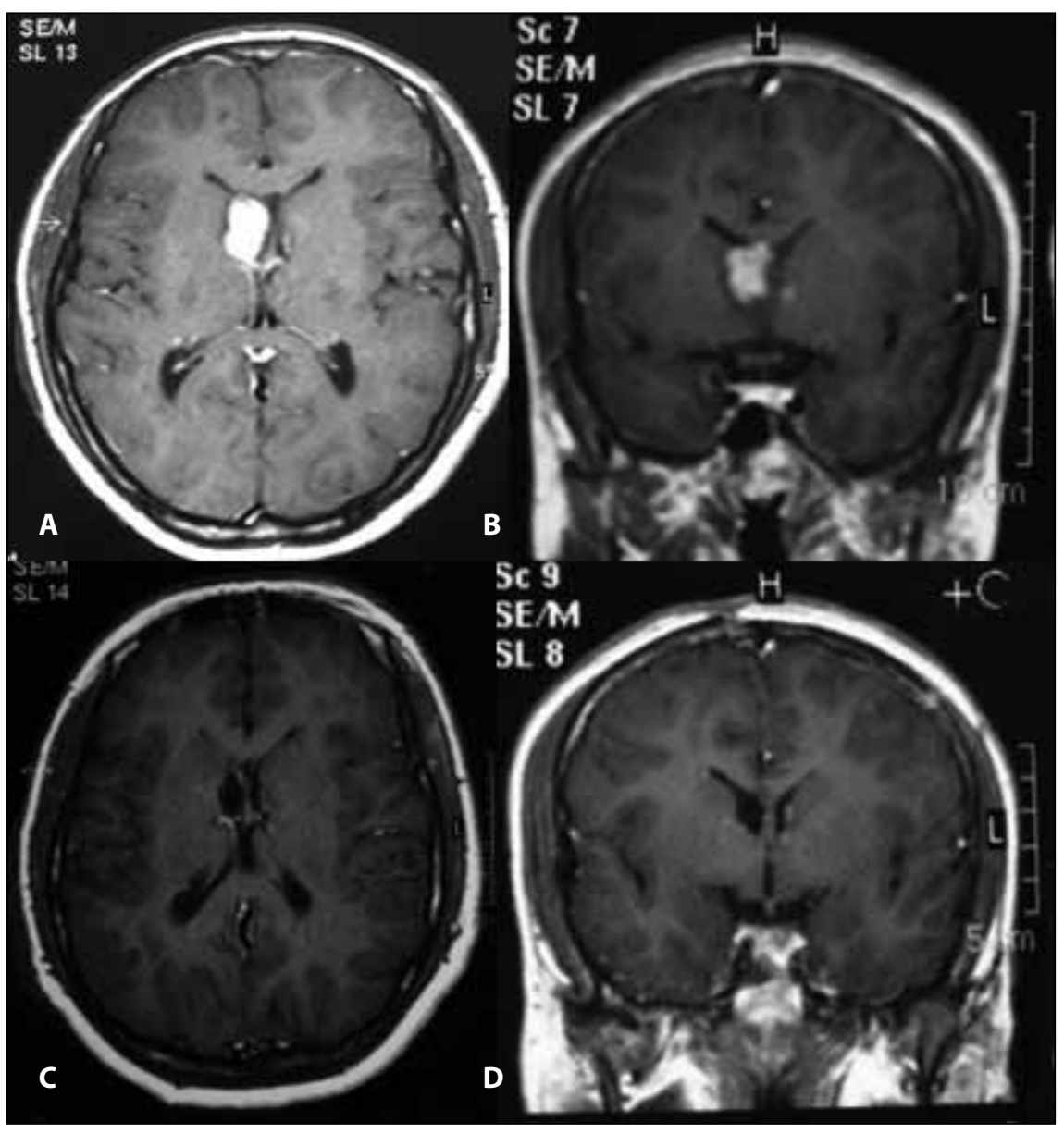

Figure 3: A) Preoperative axial MR section with contrast, the lesion was shown in the right laterale ventricule near to the foramen monro.

B) Preoperative coronal MR section with contrast also showed the tumor next to the foramen monro.

C) Postoperative axial MR section with contrast demonstrated that the lesion was totally removed.

D) Postoperative coronal MR section with contrast also showed that the lesion was totally removed.

Table I: Diagnostic Criteria for Tuberous Sclerosis Complex (TSC)

\begin{tabular}{|c|c|}
\hline Major features & Minor features \\
\hline Facial angiofibromas or forehead plaque & Dental pits (more than 14), randomly distributed \\
\hline Nontraumatic ungual or peringual fibroma & Hamartomatous rectal polyps \\
\hline Hypopigmented macules (more than 3) & Bone cysts \\
\hline Shagreen patch (connective tissue nevus) & Cerebral white matter radial migration lines \\
\hline Cortical tuber & Gingival fibromas \\
\hline Subependymal nodule & Nonrenal hamartomas \\
\hline Subependymal giant cell astrocytoma & Retinal achromic patch \\
\hline Multible retinal nodular hamortomas & Confetti skin lesions \\
\hline Cardiac rhabdomyoma, single or multible & Multible renal cysts \\
\hline \multicolumn{2}{|l|}{ Lymphangiomyomatosis } \\
\hline \multicolumn{2}{|l|}{ Renal angiomyolipoma } \\
\hline Definite TSC & 2 major features or 1 major +2 minor features \\
\hline Probable TSC & 1 major + 1 minor features \\
\hline Possible TSC & 1 major features or $\geq 2$ minor features \\
\hline
\end{tabular}

From Roach ES, Gomez MR, Northrup H. Tuberous Sclerosis Complex Consensus Conference: Revised clinical diagnostic criteria. J Child Neurol. 13: 624-628, 1998. 
the right lateral ventricle was reached. The anterior and posterior margin of the tumor was found and debulked with ultrasonic surgical aspirator (CUSA). The tumor was resected completely and the foramen monro was opened. The lesion was macroscopically consistent with astrocytomas, and was moderately hemorrhagic and infiltrative to the neural tissue level the near of the foramen of monro. The postoperative course was uneventful. Histological examination disclosed a highly cellular neoplasm with marked pleomorphism. Pleomorphic multinucleated eosinophilic tumor cells were found (x200, H-E) (Figure 6). The picture was consistent with SEGA.

\section{Patient 4}

A 16-year-old girl presented with seizures. The patient had been diagnosed with tuberous sclerosis when she was 3 months old. MRI and computed tomography (CT), performed for seizures, revealed hyperintense right ventricular lesions and periventricular neurotubers (Figure 7A-C). She had mental retardation and adenoma sebaceum, and a single intracardiac tumor, hypomelanotic macules on the skin besides the MRI and CT findings (Table III). Having no signs and symptoms of increased intracranial pressure symptoms on the examination, the patient was diagnosed with tuberosclerosis and treated with two antiepileptic drugs (vigabatrin and sodium valproate). Since the patient has had no complaints of the seizures and increased intracranial pressure symptoms so far, she has not been operated.

\section{Patient 5}

A 9-year-old girl presented with seizures. The patient had been diagnosed with tuberous sclerosis when she was 14 months old. Because of the seizures MRI and computed tomography (CT) were performed, which revealed hyperintense left vetricular lesion and periventricular neurotubers (Figure 8 A-C). He had mental retardation and adenoma sebaceum, and Shagreen patch, hypomelanotic macules on the skin besides the MRI and CT findings (Table III). The patient had no sign and symptom of increased intracranial pressure on the examination. Thus, She was diagnosed with tuberosclerosis were given was treated with two antiepileptic drugs (vigabatrin and sodium valproate). The patient has had neither complaints of the seizures nor symptoms of increased intracranial pressure so far. In addition to this, the size of the intraventricular mass volume has not changed (Figure 8D). Therefore, the patient has not been operated on until now.

\section{RESULTS}

A total of 37 patients, with a mean age of 63.6 months, 21 female and 16 male, were included in the study. Table II presents the findings from all the patients, and table 3 the clinical findings from the 5 patients with SEGA.

Table II: Tuberosclerosis Clinical Findings of the 37 Patietns

\begin{tabular}{|c|c|c|c|}
\hline \multicolumn{2}{|l|}{ Features } & $N=37$ & $\%$ \\
\hline \multicolumn{2}{|l|}{ Mean age } & & 63.6 month \\
\hline \multirow{2}{*}{ Gender } & Male & 16 & 43.2 \\
\hline & Female & 21 & 56.8 \\
\hline \multirow{5}{*}{ Neurologic } & Subependimal nodules & 27 & 73 \\
\hline & SEGA & 5 & 13,5 \\
\hline & Convulsion & 20 & 54,1 \\
\hline & Mental retardation & 18 & 48.6 \\
\hline & West syndroma & 6 & 16.22 \\
\hline \multirow{5}{*}{ Cutaneus } & hypomelanotic macules & 34 & 91,9 \\
\hline & adenoma sebaceum & 12 & 32,4 \\
\hline & "shagreeen" patch & 6 & 16,2 \\
\hline & subungual fibroma & 1 & 2,7 \\
\hline & fibroadenom in the neck & 1 & 2,7 \\
\hline \multirow{4}{*}{ Renal } & Angiomyolipomas & 14 & 37,8 \\
\hline & Polycyst & - & - \\
\hline & Simple cysts & - & - \\
\hline & Renal-cell carcinoma & - & - \\
\hline \multicolumn{2}{|c|}{ intracardiac tumor } & 14 & 37,8 \\
\hline \multicolumn{2}{|c|}{ Retinal hamartomas } & - & - \\
\hline \multicolumn{2}{|l|}{ Bone cyst } & - & - \\
\hline
\end{tabular}




\section{Neurological findings:}

Our patients were admitted to hospital primarily because of convulsion. There were 20 (54.1\%) patients with convulsion in our study. Subependymal nodule was the most frequent finding in cranial imaging. Subependimal nodules were detected in $27(73 \%)$, cortical tubers in $19(51,4 \%)$, and giant cell astrositomas in $5(13,5 \%)$ patients. Mental retardation at varying degrees was detected in 18 of the patients (48.6).

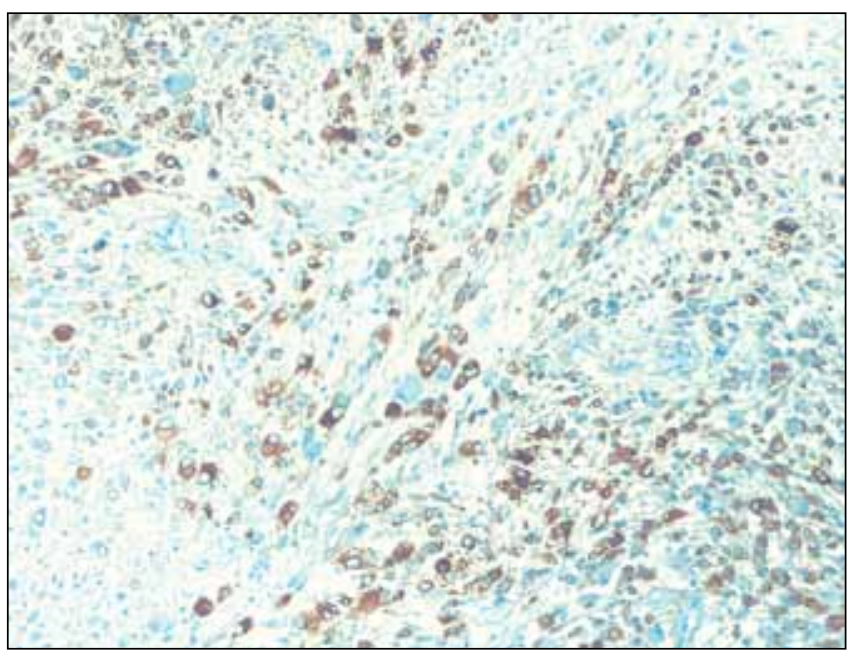

Figure 4: Tumor cells demonstrated GFAP positivity (x100, Immunoperoxidase).
West syndrome was in 6 patients (16.22\%). There were 3 female and 2 male patients with SEGA. The age range at the time of surgery was 10-18 years, with a mean of 15 years. Four children who did not show any progressive neurological deficit related to the intraventricular lesion were admitted because sequential neuroimaging studies revealed the growth of "subependymal nodules" into the intraventricular tumours, and these four patients with epileptic seizures resistant to a combination of anticonvulsant agents, were diagnosed as having TS by pathognomonic features. In the remaining one patient, headache was the first and only sign of a CNS disease. This patient was admitted because of the symptoms of increased intracranial pressure, such as progressive headaches, nausea, vomiting.

\section{Cutaneus finding:}

Of the patients, $34(91,9 \%)$ had hypomelanotic macules in our study. There were hypopigmented lesions on the skin of 34 patients $(91,9 \%)$. In 12 of the patients $(32,4 \%)$ adenoma sebaceum, in 6 of the patients $(16,2 \%)$ "shagreeen" patch, in one of the patients $(2,7 \%)$ subungual fibroma and in one of them $(2.7 \%)$ fibroadenoma in the neck were detected.

\section{Cardiac, renal and eye findings}

Cardiological assessment revealed an intracardiac mass in 14 of the patients (37.8\%). Renal USG of these patients demonstrated angiomyolipoma. The ophthalmic and lung examination revealed no pathological finding.

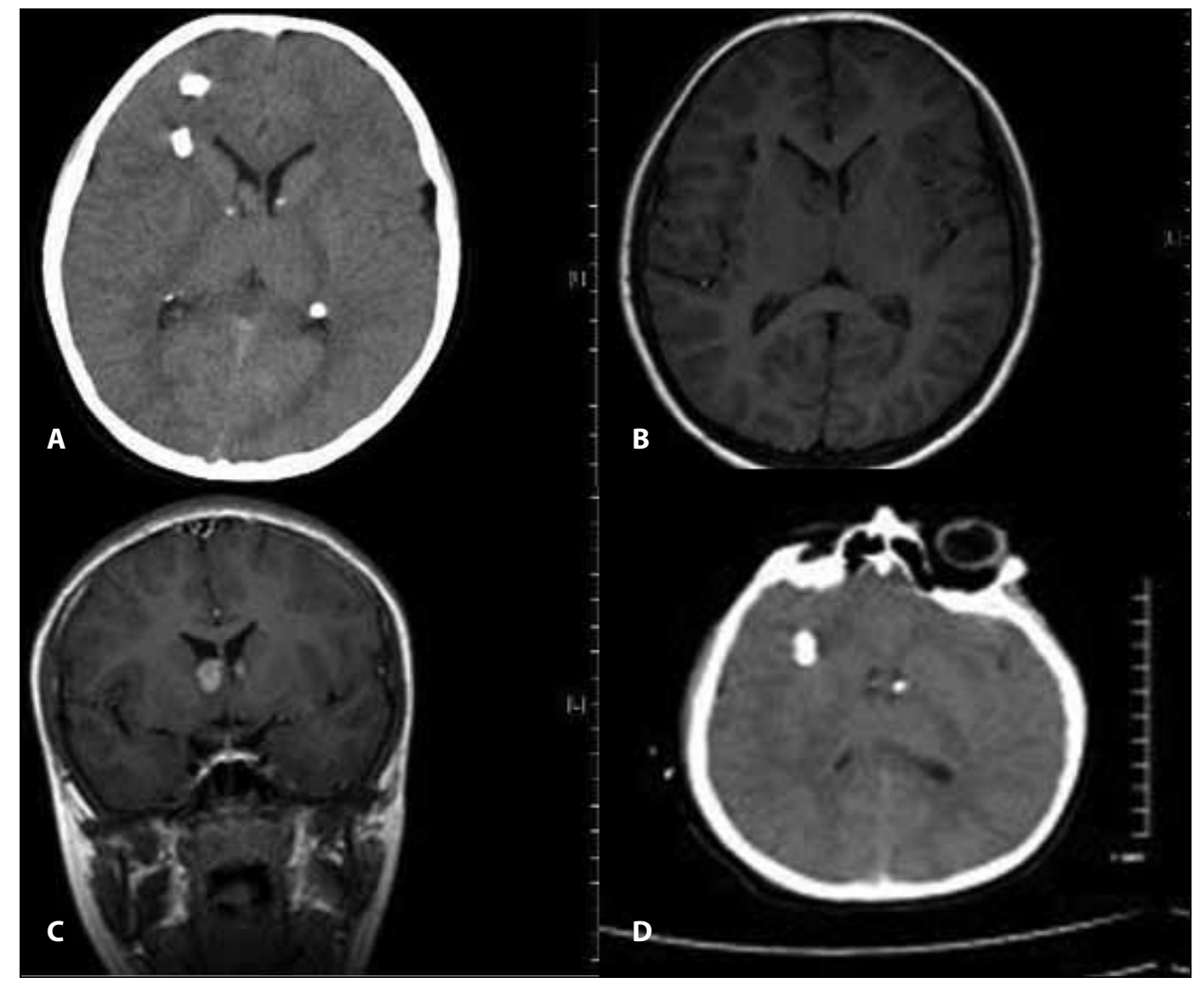

Figure 5: A) Preoperative axial CT section with no contrast showed hypodense tumor in the right laterale ventricule and intraparenchymal neurotubers.

B) Preoperative axial MR section with no contrast also showed that the tumor was isointense with neural tissue. C) Preoperative coronal MR section with contrast showed that the tumor located on the right laterale ventricule and next to the foramen monro. D) Postoperative axial CT section demonstrated that the tumor was totally removed. 


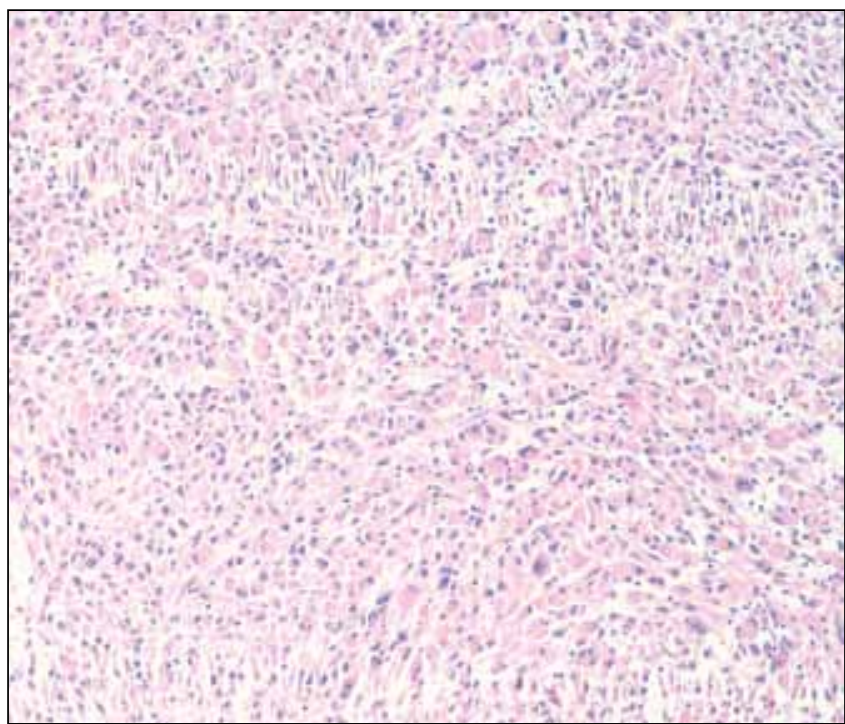

Figure 6: Pleomorphic multinucleated eosinophilic tumor cells (x200,H-E).

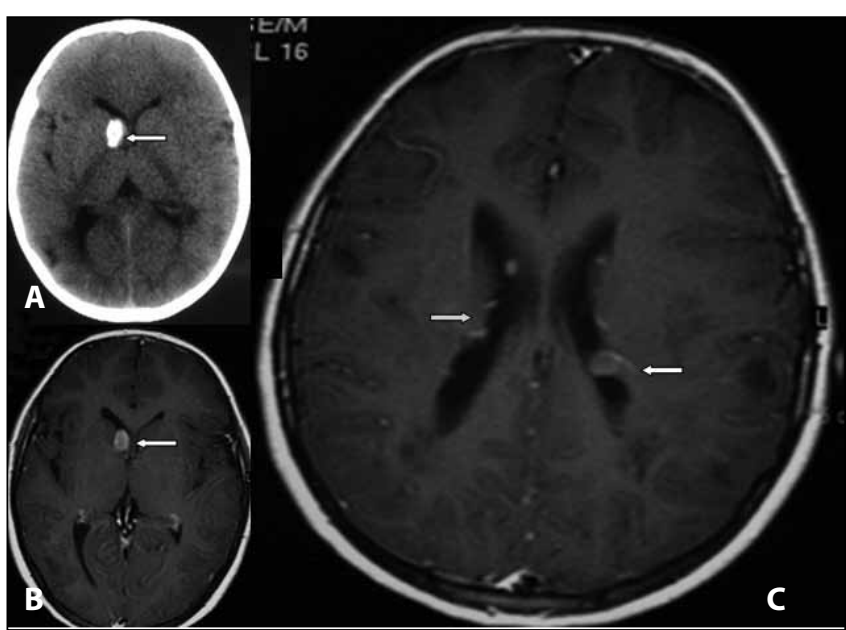

Figure 7: A) Hyperintense lesion is being seen axial CT section located on right lateral ventricule (arrow), B) The dense contrast enhancement has been shown axial MR section (arrow), C) Periventricular subependymal neurotubers have also been shown on axial MR section with contrast (arrow).

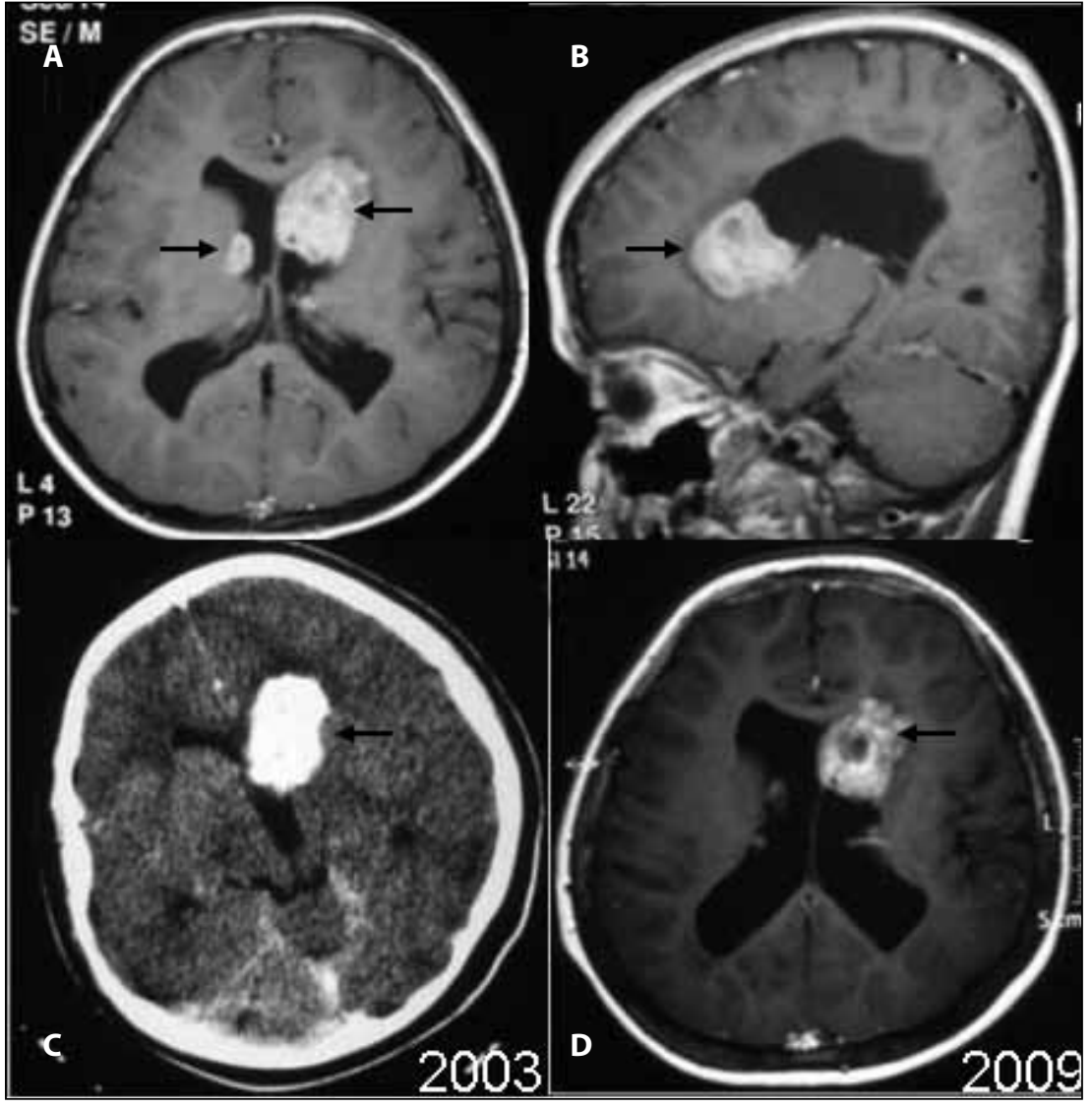

Figure 8: A) Giant cell astrocytoma is being seen in the MR axial section with contrast located on left ventricule (arrow) (year 2001). B) The lesions are being seen in the MR saggital section with contrast (arrow) (year 2001).

C) Compute thomography was revealed the lesions (arrow) (year 2003).

D) The lesions have shown in the MR axial section with no changes its volume (arrow) (year 2009).

\section{DISCUSSION}

The first reason for morbidity and mortality is neurological complications and the second one is renal involvement.

The neurological complications of TSC are the most common and often the most impairing aspect of this disease. In brain tissue, mutations in the TSC 1 and TSC 2 genes cause abnormal neuronal and glial differentiation and proliferation as well as abnormal cellular migration. TSC derives its name from cortical tubers, so called for their gross pathologic "potatolike" appearance (9). They occur in as many as $95 \%$ of patients $(3,17)$. Tubers most commonly involve surface cortical and 
Table III: Clinical Findings of the 5 Patients with Tuberous Sclerosis Complex

\begin{tabular}{|l|c|c|c|c|c|}
\hline Features & Case 1 & Case 2 & Case 3 & Case 4 & + \\
\hline Giant cell astrocytoma & + & + & + & - & + \\
\hline Cortical tuber & + & + & + & + & + \\
\hline Hypomelanotic macules & + & + & - & + & + \\
\hline Adenoma sebaceum & + & - & + & + & - \\
\hline Renal Angiomyolipomas & - & + & - & - \\
Cardiac rhabdomyoma & + & - & - & + \\
\hline Shagreen patch & - & - & + & + \\
\hline Subependymal nodule & - & + & + & + \\
\hline
\end{tabular}

subcortical areas but may also be seen in the cerebellum. Their architecture expands the gyri and disrupts the graywhite matter junction. Tubers vary in size from millimeters to centimeters and are frequently multiple $(4,10,17,19,27)$.

Subependymal nodules are also seen in the majority of TSC patients. They can be identified early in infancy and increase in number through the first decade of life. Histologically, they are hamartomatous lesions formed from dysplastic astrocytic and neuronal cells. Radiographically, SENs appear as small protrusions into the walls of the lateral ventricles, giving the pathologic appearance of "candle guttering." SENs are most commonly found around the area of the foramen Monro. They tend to calcify with time and for this reason are often more easily identified on CT imaging (1, 4, 16, 17, 27). Literature proposes that subependymal nodules a turn into tumor as a risk factor when they are greater than $5 \mathrm{~mm}$, with incomplete calcification and contrast enhancement. Therefore, if the nodules are located near the foramen monro, MRI should be performed every year up to 10 years of age (22).

Research has shown that tubers and SEGAs express similar neuroglial markers and thus likely to originate from a defect in progenitor cell differentiation during brain development. SEGAs are clinically significant because enlargement of these lesions may obstruct the flow of cerebrospinal fluid at the foramen of Monro, causing obstructive hydrocephalus. These lesions are benign slow-growing grade I tumors containing giant cells with morphologic features of glia. Although traditionally classified as an astrocytic tumor, many SEGAs also exhibit a mixed glioneuronal phenotype and express both neuronal as well as astrocytic markers. In addition, SEGAs may develop directly from a subependymal nodule or possibly originate de novo from an unidentified cell type. Surgical resection of the lesion has been accepted as the treatment of choice but the timing of surgery remains debatable. Some surgeons advocate early surgery, while others offer waiting for symptomatic lesions or hydrocephalus. In children, 110 cases of subependymal giant cell astrocytomas have been reported in the literature. They were usually discovered after 10 years, at a mean age of 13 years $(5,9,16,17,20,22)$. SEGA's were detected in five of the patients. The age range at the time of surgery was $10-18$ years, with a mean of 15 years in our patients.
In this study, 3 patients were operated on in elective conditions. In one case there were signs of high intracranial pressure on fundoscopic examination for pupil edema, but no signs of transforominal herniation. In another case the patients' parents did not consent to the surgery and the other patient had no high intracranial pressure sign on fundoscopy and no tumor growing on the MRI.

According to literature, SEGAs are seen by $2-14 \%(22,29,30)$. The nature of the SEGAs is benign and slowly growing but they can lead to sudden deterioration in the patient's clinic condition due to foramen monro obstruction related with their localization.

Causes of foramen monro obstruction are described as intratumoral bleeding and tumor volume increasing. Foramen of monro obstruction results in high intracranial pressure. It is reported that if the characteristics of the nodule have a noncalcification, contrast enhancement and near localization to the foramen of monro, these characteristics might be described as high risk factor for tumor transformation (22).

When the patients underwent emergency surgery, mortality rate reached approximately $10 \%$ and when the tumoral resection is done in selective conditions, patients outcome were improved (23).

Ribaupierre et al (8) reported that if the radiological characteristics of the SEGA have an incomplete or noncalcification, with a location near the foramen of monro and a size greater than $5 \mathrm{~mm}$, the lesions should be excised as early as possible. Their numbers were larger or symptomatic lesions tend to have a higher morbidity.

Patients with SEGAs might be able to present different neurological symptoms to the clinic, which include not only increased ICP symptoms, epilepsy, behavioral modification but also acute hydrocephalus due to foramen of monro obstruction or intraventricular hemorrhage $(2,12)$.

Moncef Berhouma (2) reports that if there is evidence of growth on the successive MRI, tumors should be removed early as soon as possible.

According to the literature, early surgical approach is advised $(2,6,13,33)$. 
In this study, the tumor in patient 1 was resected subtotally because of the adhesion to the head of the caudate nucleus. It is reported that large tumors have had some drawbacks during surgery due to the deformation of the foramen of monro like difficulties in operative hemostasis and dissection from surrounding structures (2)

SEGA is diagnosed in adolescents as a part of the tuberous sclerosis (TSC) complex, but it can be seen without any associated stigmata of TSC. Surgery is the preferred treatment and should be done as soon as SEGA is diagnosed, because early diagnosis and treatment can reduce surgical morbidity and risk of tumor recurrence. MRI should be performed at the time of diagnosis of tuberous sclerosis When there are nodules located near the foramen of Monro and if they measure $>5$ $\mathrm{mm}$ in diameter, are not or incompletely calcified, and are enhanced by gadolinium, MRI should be repeated every year until the age of 15 years. $(1,3,5,9,11,17,22,27,31,32,34)$. In our study, subependymal nodule was the most frequent symptom detected in the cranial imaging. In 27 of the patients (73\%) subependymal nodules, in 19 of them $(51,4 \%)$ cortical tubers, in 5 of them $(13,5 \%)$ giant cell astrocytoma were detected. Four children who did not show any progressive neurological deficit related to the intraventricular lesion were admitted because sequential neuroimaging studies revealed the growth of 'subependymal nodules' into the intraventricular area, and these four patients who had epileptic seizures resistant to a combination of anticonvulsant agents, were diagnosed as having TS by pathognomonic features. In the remaining one patient, headache was the first and only sign of a CNS disease.

More than $80 \%$ of patients experience seizures, and 50 to $80 \%$ have mild to severe cognitive impairment. Sudden deaths in TS patients have been described. Seizures are the presenting symptom in $92 \%$ of individuals with TSC, making epilepsy a significant cause of morbidity associated with this disease. Seizure onset usually occurs during infancy or early childhood but may happen at any age $(18,27,28)$. There was no mortality in our series. Twenty patients (54\%) were admitted to hospital with the complaints of having convulsion in our study. Tuberous sclerosis was detected in the etiology of 6 of our patients being followed with the diagnosis of west syndrome.

Cognitive dysfunction has long been recognized as a common neurological complication of TSC. It was previously assumed that mental retardation was inevitable, but more recent studies have shown that many affected individuals may have normal intelligence. Cognitive abnormalities have been found in about $50 \%$ to $65 \%$ of patients in earlier population-based studies, but the results in these studies were not based on standardized psychometric evaluations $(15,27)$. In our study, mental retardation was detected by $48.6 \%$, a rate that was in various levels (mild 19\%, medium 22\%, serious $8 \%$ ). This rate is similar to that which is in the literature.

The renal manifestations of TSC are found in a majority of patients. They include angiomyolipomas (AMLs), simple cysts, polycystic kidney disease, and renal-cell carcinoma. AMLs are found in as many as $80 \%$ of patients with TSC, but are typically asymptomatic $(14,26,27)$. After the renal USG, performed to the patients, angiomyolipoma was detected in the 14 of the patients (37,8\%).

The cutaneous manifestations in TSC are common, and are typically the first clue to the diagnosis. They include hypomelanotic macules, facial angiofibroma, forehead plaques, shagreen patches, and ungual fibromas. Hypomelanotic macules or ash leaf spots occur in $61 \%$ to $97.2 \%$ of individuals with TSC. Facial angiofibromas (adenoma sebaceum) are pathognomonic for TSC and are seen in over $70 \%$ of patients. They first appear during the preschool years and with time develop into discrete, papular, pink, or erythematous lesions in a symmetrical malar distribution on the face $(26,27)$.

Cardiac rhabdomyomas are the most common intracardiac tumor of infancy and childhood, and are highly associated with TSC. They are found in $30 \%$ to $50 \%$ of affected individuals (25-28). In this study, after the cardiological assessment intracardiac mass has been detected in the 14 of the patients $(37,8 \%)$.

In conclusion, a multidisciplinary approach is essential for an early, accurate diagnosis and proper management of affected individuals. In the light of the literature, we concluded that early and planned surgery was suggested although we operated on the patients in chosen conditions.

\section{REFERENCES}

1. Baron Y, Barkovich AJ: MR Imaging of tuberous sclerosis in neonates and young infants. AJNR 20: 907-916, 1999

2. Berhouma M: Management of subependymal giant cell tumors in tuberous sclerosis complex: the neurosurgeon's perspective. World J Pediatr 6(2): 103-110, 2010

3. Braffman BH, Bilaniuk LT, Naidich TP, Altman NR, Post MJ, Quencer RM, Zimmerman RA, Brody BA: MR imaging of tuberous sclerosis: Pathogenesis of this phakomatosis, use of gadopentetate dimeglumine, and literature review. Radiology 183: 227-238, 1992

4. Chou IJ, Lin KL, Wong AM, Wang HS, Chou ML, Hung PC, Hsieh MY, Chang MY: Neuroimaging correlation with neurological severity in tuberous sclerosis complex. Eur J Paediatr Neurol 12: 108-112, 2008

5. Chow CW, Klug GL, Lewis EA: Subependymal giant-cell astrocytoma in children. An unusual discrepancy between histological and clinical features. J Neurosurg 68: 880-883, 1988

6. Cuccia V, Zuccaro G, Sosa F, Monges J, Lubienieky F, Taratuto AL: Subependymal giant cell astrocytoma in children with tuberous sclerosis. Childs Nerv Syst 19: 232-243, 2003

7. Dabora SL, Jozwiak S, Franz DN, Roberts PS, Nieto A, Chung J, Choy YS, Reeve MP, Thiele E, Egelhoff JC, Kasprzyk-Obara J, Domanska-Pakiela D, Kwiatkowski DJ: Mutational analysis in a cohort of 224 tuberous sclerosis patients indicates increased severity of TSC2, compared with TSC1, disease in multiple organs. Am J Hum Genet 68: 64-80, 2001 
8. de Ribaupierre S, Dorfmüller G, Bulteau C, Fohlen M, Pinard JM, Chiron C, Delalande O: Subependymal giant-cell astrocytomas in pediatric tuberous sclerosis disease: When should we operate? Neurosurgery 60(1): 83-90, 2007

9. DiMario FJ Jr: Brain abnormalities in tuberous sclerosis complex. J Child Neurol 19: 650-657, 2004

10. Eluvathingal TJ, Behen ME, Chugani HT, Janisse J, Bernardi B, Chakraborty P,Juhasz C, Muzik O, Chugani DC: Cerebellar lesions in tuberous sclerosis complex: Neurobehavioral and neuroimaging correlates. J Child Neurol 21: 846-851, 2006

11. Ess KC, Kamp CA, Tu BP, Gutmann DH: Developmental origin of subependymal giant cell astrocytomas in tuberous sclerosis complex. Neurology 64: 1446-1449, 2005

12. Fujiwara S, Takaki T, Hikita T, Nishio S: Subependymal giantcell astrocytoma associated with tuberous sclerosis. Do subependymal nodules grow? Childs Nerv Syst 5(1): 43-44, 1989

13. Goh S, Butler W, Thiele EA: Subependymal giant cell tumors in tuberous sclerosis complex. Neurology 63:1457-1461, 2004

14. Harabayashi T, Shinohara N, Katano H, Nonomura K, Shimizu $\mathrm{T}$, Koyanagi $\mathrm{T}$ : Management of renal angiomyolipomas associated with tuberous sclerosis complex. J Urol 171: 102-105, 2004

15. Harrison JE, O'Callaghan FJ, Hancock E, Osborne JP, Bolton PF: Cognitive deficits in normally intelligent patients with tuberous sclerosis. Am J Med Genet 88: 642-646, 1999

16. Hosoya M, Naito H, Nihei K: Neurological prognosis correlated with variations over time in the number of subependymal nodules in tuberous sclerosis. Brain Dev 21: 544-547, 1999

17. Inoue $Y$, Nemoto $Y$, Murata R, Tashiro T, Shakudo M, Kohno $\mathrm{K}$, Matsuoka O, Mochizuki K: CT and MR imaging of cerebral tuberous sclerosis. Brain Dev 20: 209-221, 1998

18. Jansen FE, van Huffelen AC, Algra A, van Nieuwenhuizen O: Epilepsy surgery in tuberous sclerosis: A systematic review. Epilepsia 48: 1477-1484, 2007

19. Luat AF, Makki M, Chugani HT: Neuroimaging in tuberous sclerosis complex. Curr Opin Neurol 20: 142-150, 2007

20. Menor F, Marti-Bonmati L, Mulas F, Poyatos C, Cortina H: Neuroimaging in tuberous sclerosis: A clinicoradiological evaluation in pediatric patients. Pediatr Radiol 22:485-489, 1992

21. Mizuguchi M, Takashima S: Neuropathology of tuberous sclerosis. Brain Dev 23: 508-515, 2001

22. Nabbout R, Santos M, Rolland Y, Delalande O, Dulac O, Chiron C: Early diagnosis of subependymal giant cell astrocytoma in children with tuberous sclerosis. J Neurol Neurosurg Psychiartry 66: 370-375, 1999
23. Nagib MG, Haines SJ, Erickson DL, Mastri AR: Tuberous sclerosis: A review for the neurosurgeon. Neurosurgery 14(1): 93-98, 1984

24. Osborne JP, Fryer A, Webb D: Epidemiology of tuberous sclerosis. Ann N Y Acad Sci 615: 125-127, 1991

25. Quek SC, Yip W, Quek ST, Chang SK, Wong ML, Low PS: Cardiac manifestations in tuberous sclerosis: A 10-year review. J Paediatr Child Health 34: 283-287, 1998

26. Roach ES, Gomez MR, Northrup H:Tuberous sclerosis complex consensus conference: Revised clinical diagnostic criteria. J Child Neurol 13: 624-628, 1998

27. Rosser T, Panigrahy A, McClintock W: The diverse clinical manifestations of Tuberous Sclerosis Complex: A review. Semin Pediatr Neurol 13: 27-36, 2006

28. Schwartz RA, Fernández G, Kotulska K, Jóźwiak S: Tuberous sclerosis complex: Advances in diagnosis, genetics, and management. J Am Acad Dermatol 57: 189-202, 2007

29. Shepherd CW, Scheithauer BW, Gomez MR, Altermatt HJ, Katzmann JA:Subependymal giant cell astrocytoma: A clinical, pathological, and flow cytometric study. Neurosurgery 28(6): 864-868, 1991

30. Shepherd CW, Scheithauer B, Gomez MR: Brain tumors in tuberous sclerosis. A clinicopathologic study of the Mayo Clinic experience. Ann N Y Acad Sci 615: 378-379, 1991

31. Sinson G, Sutton LN, Yachnis AT, Duharime AC, Schut L: Subependymal giant cell astrocytomas in children. Pediatr Neurosurg 20: 233-239, 1994

32. Sparagana SP, Roach ES: Tuberous sclerosis complex. Curr Opin Neurol 13: 115-119, 2000

33. Torres OA, Roach ES, Delgado MR, Sparagana SP, Sheffield E, Swift D, Bruce D: Early diagnosis of subependymal giant cell astrocytoma in patients with tuberous sclerosis. J Child Neurol 13(4): 173-177, 1998

34. Turgut M, Akalan N, Ozgen T, Ruacan S, Erbengi A: Subependymal giant cell astrocytoma associated with tuberous sclerosis: Diagnostic and surgical characteristics of five cases with unusual features. Clin Neurol Neurosurg 98: 217-221, 1996

35. Wiederholt WC, Gomez MR, Kurland LT: Incidence and prevalence of tuberous sclerosis in Rochester, Minnesota, 1950 through 1982. Neurology 35: 600-603, 1985

36. Wienecke RW, Maize JC, Reed JA, de Gunzburg J, Yeung RS, DeClue JE: Expression of the TSC2 product tuberin and its target Rap1 in normal human tissues. Am J Pathol 150: 43-50, 1997 